\title{
Döviz Piyasasının Etkinliği: Türkiye için Bir Analiz
}

\author{
Efficiency of The Foreign Exchange Rate Market: An Analysis for Turkey
}

Burcu BERKE ${ }^{1}$, Burcu ÖZCAN² ${ }^{2}$ Hatice Işın DiZDARLAR ${ }^{3}$

\begin{abstract}
ÖZET
Literatürde, döviz piyasasının etkinliği, döviz alım-satımı yapanlar ve politika yapıcılar için önemli bir kavram olup bir piyasada fiyat tüm bilgi setini yansıtıyor ise bu piyasanın etkin olduğu ifade edilmektedir. Bir diğer ifadeyle, Fama vd. (1969) etkin piyasa terimini "yeni bilgiye hızlı biçimde intibak eden" bir piyasa şeklinde tanımlamışlardır. Zayıf form etkinlikte, piyasada tüm fiyatlar, geçmiş fiyatlar veya getirilerde elde edilebilir tüm bilgiyi yansıtırken, yarı güçlü form etkinlikte ise döviz kurları sadece geçmiş döviz kurlarına ilişkin bilgiyi değil aynı zamanda diğer döviz kurları ve makroekonomik değişkenlere ilişkin bilgiyi de yansıtmaktadır. Bu çalışmanın temel amacı, Türkiye'de 2006:04-2013:12 döneminde TL/\$ ve TL/Euro döviz piyasalarının zayıf ve yarı güçlü formlarda etkin olup olmadığını yapısal kırılmalı birim kök ve eşbütünleşme yöntemleriyle analiz etmektir. Analiz sonuçları, Türk döviz piyasasının zayıf formda etkin olduğunu gösterirken, yarı güçlü formda etkin olmadığını ve forward kur yansızlık hipotezinin Türkiye için geçerli olmadığını ortaya koymaktadır.
\end{abstract}

Anahtar Kelimeler: Türk döviz piyasası, zayıf ve yarı güçlü formlarda etkinlik, forward yansızık hipotezi, yapısal kırılmalı birim kök ve eşbütünleşme testleri

\section{Gíriş}

Araştırmacıların, döviz alım-satımı yapanların (traders) ve politika yapıcıların döviz kurlarının piyasalarda etkin bir şekilde belirlenip belirlenmediğine ilişkin büyüyen bir ilgi vardır. Döviz kurlarının piyasalarda etkin bir şekilde belirlenmesi piyasa denge fiyatının oluşmasıyla ilişkili bir kavramdır. Etkin piyasalarda oluşan fiyatların piyasaya gelen her türlü bilgiyi içermesi ve piyasalarda iktisadi birimlerin denge fiyatlar üzerinden üretim, tüketim ve kaynak kullanımı ile ilgili en uygun kararı verebilecekleri beklenmektedir (Abaan, 1995: 256).

Campell vd. (1997: 20), literatürde etkin piyasa tartışmalarının Bachelier (1900)'ın teorik katkısına ve Cowles (1993)'ın ampirik analizine kadar uzandığını ifade etmişlerdir. Ayrıca, iktisat yazınında konuyla ilgili literatürün Samuelson (1965)'nın Bachelier ve Cowles'ın çalışmalarını özetlediği "Proof that properly anticipated price fluctuate randomly" adlı makale ile başladığı öne sürülmüştür.

\begin{abstract}
In the literature, the effectiveness of the foreign exchange market is an important concept for traders and policy makers, if price reflects all information in the market, this market is said to be efficient. In other words, Fama et al. (1969) term of the efficient market were defined as a market which " adapt quickly to new information". At the weak form efficiency, in the market, all prices, past prices or returns can be reflected in all the information, on the other hand, at the semi-strong form efficiency, the exchange rates are not only reflect past information concerning exchange rates, but also they are reflect other currency exchange rates and information concerning macroeconomic variables. The main purpose of this study is whether TL / \$ and TL / Euro exchange rate markets are efficient at the weak and semi-strong form or not is to analyze by using unit root and cointegration methods with structural breaks during the period 2006:04-2013:12 in Turkey. Analysis results show that the Turkish foreign exchange market is efficient at the weak form and not efficient at the semi-strong form and forward rate unbiasedness hypothesis is not valid for Turkey.
\end{abstract}

Keywords: Turkish foreign exchange market, weak and semistrong form efficiency, forward unbiasedness hypothesis, unit root and cointegration tests with structural breaks.

Literatürde etkin piyasa kavramını ilk olarak Fama açıklamıştır (Rapp ve Sharma, 1999: 423). Fama (1965: 39), rasyonel davranan ve karını maksimize etmek isteyen piyasa katılımcılarının menkul değerlerin gelecekteki değerlerini tahmin ederken, piyasada aktif olarak rekabet ettiği ve tüm katılımcıların önemli güncel bilgileri serbestçe elde edilebildiği piyasaları "etkin piyasalar" (efficient markets) olarak tanımlamıştır. Etkin piyasa hipotezinin kaynakları, Fama (1970, 1991, 1998)'ya dayandırılmaktadır. Bu çalışmalarda, piyasada fiyatlar tamamen tüm elde edilebilir (mevcut) ve önemli (relevant) bilgiyi yansıtıyor ise piyasanın bilgisel olarak etkin olduğu ifade edilmiştir (Mehrara ve Oryare, 2012: 165). Bilgisel olarak etkin bir piyasada, piyasa tüm piyasa katılımcılarının beklentilerini ve bilgilerini tamamen içeriyor ise fiyat değişimleri öngörülememelidir (Iwatsubo ve Kitamura, 2008). Bu perspektiften etkin bir piyasada fiyat değişmeleri sadece yeni bilginin varışı ile gerçekleşmektedir. Ancak, gelecek bilgi öngörülemediği için elde edilebilir bilgi setine göre gelecek fiyat değişmelerinin

\footnotetext{
${ }^{1}$ Yrd.Doç.Dr.,Niğde Üniversitesi, i̇ktisadi ve İdari Bilimler Fakültesi, i̇ktisat Bölümü, burcuberke@nigde.edu.tr

2 Doç.Dr., Fırat Üniversitesi, İktisadi ve İdari Bilimler Fakültesi, İktisat Bölümü, bozcan@firat.edu.tr

${ }^{3}$ Yrd.Doç.Dr., Niğde Üniversitesi, İktisadi ve İdari Bilimler Fakültesi, İşletme Bölümü, dizdarlar@nigde.edu.tr
} 
öngörülmesi ve iktisadi karların yapılması mümkün değildir (Mehrara ve Oryare, 2012: 165). Aynı zamanda piyasa etkinliği hipotezinde alım-satım yapanların spekülasyon yaparak fazla getiri (excess return) elde etmeleri de söz konusu değildir (MacDonald ve TayIor, 1992: 28). Etkin bir piyasada fiyatlar, tüm önemli ve mevcut bilgiyi tamamen yansıtmalı, bu nedenle de hiçbir kar fırsatı keşfedilmemiş kalmamalıdır (Rapp ve Sharma, 1999: 423).

Bir piyasada fiyat tamamen bilgi setini yansıtıyor (Fama, 1970) ve fiyat, tüm piyasa katılımcılarınca bilgi seti açığa çıkarılarak etkilenmiyor ise piyasa bu bilgi setine göre etkindir (Sewell, 2011: 2). Varlık fiyat değişimleri bütün piyasa katılımcılarının sahip olduğu bilgiyi ve piyasa katılımcılarının beklentilerini tam olarak yansıtıyor ise bilgi etkinliği olan piyasalarda fiyat değişimlerini tahmin etmek mümkün değildir. Burada dikkat edilmesi gereken nokta Pareto etkin piyasa veya dağıtım etkinliği olan piyasanın bilgi etkinliğine sahip piyasa ile karıştırılmamasıdır (Campell vd., 1997: 20). Ancak, Stiglitz (1981) açıkça rekabetçi ve etkin piyasalarla bile kaynak dağılımlarının Pareto etkin olmayabileceğini göstermiştir (Sewell, 2011: 5).

Varlık piyasalarında, fiyatların davranışı ile ilgili olan etkin piyasa hipotezinde (EMH) "etkin piyasa" terimi, başlangıçta hisse senedi piyasalarına uygulanmış, ancak, bu kavram zamanla diğer varlık piyasalarına genişletilmiştir (Wickremasinghe, 2004: 2). Etkin piyasaların aslında temel odağı sermaye piyasaları olduğundan, bu kavram, kolaylıkla döviz piyasalarına uygulanabilmiştir (Ahmad, Rhee ve Wong, 2012: 1578). Döviz piyasalarının etkinliğine yönelik ilgi finansal fiyatların bütünüyle ve eşanlı bir şekilde tüm muhtemel bilgiyi yansıtıp yansıtmadığı ve bunun iktisadi etkinliği nasıl etkilediğine ilişkin tartışmaya kadar gitmektedir (Kisaka vd., 2008). Öyle ki, döviz piyasasının etkinliği uluslararası finansın köşe taşlarından biri olup bir piyasa tamamen ve doğru biçimde ürünün fiyatını belirlemede tüm mevcut bilgiyi yansıtır ise etkindir (Dowla, 1995: 95).

Çalışmanın temel amacı, Türkiye'de 2006:042013:12 döneminde aylık veri seti kullanılarak TL/\$ ve TL/Euro döviz piyasalarının zayıf ve yarı güçlü formlarda etkin olup olmadığını yapısal kırılmalı birim kök ve eşbütünleşme yöntemleriyle analiz etmektir. Döviz piyasası etkin iken spot (forward) döviz kurları tüm önemli bilgiyi içermeli ve diğerinin bir fonksiyonu olarak spot (forward) döviz kurunu öngörmek mümkün olmamalıdır (Rapp ve Sharma, 1999: 423). Döviz piyasasının etkinliği hipotezi, forward kur sapmasızlık (forward rate unbiasedness) hipotezi (FRUH) ola- rak da adlandırılmaktadır. Çünkü, etkin bir piyasada forward döviz kuru gelecek spot kurunun sapmasız ya da iyi bir tahmincisi olmalıdır (Giannellis ve Papadopoulos, 2006). Bir diğer ifadeyle, cari forward kur, risk nötrlük ve kovaryans durağan risk primi varsayılır ise gelecek spot kurun yansız bir tahmincisi olmalıdır. Cari forward döviz kuru, piyasalar etkin ise gelecek spot kuru öngörmelidir (Rapp ve Sharma, 1999: 424). Bu amaçla, çalışmanın ikinci kısmında döviz piyasasının etkinliği ile ilgili teorik ve ampirik literatür sunulmaktadır. Çalışmanın üçüncü kısmında ampirik analiz (model) tanıtılmakta, dördüncü ve beşinci bölümlerde çalışmada kullanılan veri seti, metodoloji ve ulaşılan ampirik sonuçlara yer verilmektedir. Son olarak, çalışma sonuç bölümü ile tamamlanmaktadır.

\section{LITERATÜR INCELEMESi}

\subsection{Teorik Literatür}

Etkin piyasa terimini Fama vd. (1969) "yeni bilgiye hızıı biçimde intibak eden" bir piyasa olarak tanımlamışlardır. Fama (1970: 383) ise fiyatların elde edilen bilgileri "tam olarak yansıttığı" (fully reflect) piyasayı etkin piyasa olarak adlandırmıştır. Bu tanım, bilginin ihmal edilmediği ve sistematik hataların yapılmadığı durumlarda piyasanın bilgiyi rasyonel olarak süreçlediğine işaret etmektedir (Beechey, Gruen ve Vickery, 2000: 2). Jensen (1978) etkinliği, "bir piyasada $\theta$ bilgi seti temelinde alım-satım yapılarak iktisadi kar elde edilmesi imkansız ise bu piyasa, $\theta_{t}$ bilgi setine göre etkindir" şeklinde tanımlamıştır (Sewell, 2011: 4). Bir diğer ifadeyle, Jensen (1978: 96)'e göre bir piyasada oyuncuların hiçbiri bilinen bilgi setini kullanarak fazla kar elde edemedikleri durumda piyasa etkindir. Grossman ve Stiglitz (1980) bir piyasa için tamamen bilgisel olarak etkin olmanın imkansız olduğunu dile getirmiştir. Bilgi maliyetli olduğu için fiyatlar tamamen mevcut tüm bilgiyi yansıtmaz, çünkü, eğer fiyatlar tamamen bilgiyi yansıtsaydı, bilgiyi elde etmek ve analiz etmek için kaynak harcayan yatırımcılar bu harcamalarını karşılayacak bir gelir elde edemezlerdi. Böylece, duyarlı bir piyasa dengesi modelinde bilgi toplamak için belli ölçüde teşvik bırakılması gerekmektedir (Sewell, 2011: 5). Fama (1991: 1575) ise etkin piyasa hipotezinde, menkul değerlerin fiyatlarının piyasadaki mevcut tüm bilgiyi yansıttığını iddia ederek hipotezin ön koşulunun bilgi ve işlem maliyetleri olduğunu belirtmiştir. Dolayısıyla, etkin piyasa hipotezi için oluşturulan modelde bilgi ve işlem maliyetleri her zaman sıfır olmalıdır.

Piyasa etkinliği için diğer gerekli koşullar, bilgi ve veriler üzerinde tekelleşmenin olmaması ve işlem maliyetlerinin rekabetçi bir şekilde oluşmasıdır (Cey- 
lan ve Korkmaz, 1993: 176). Laffont ve Maskin (1990), eksik rekabet mevcut iken etkin piyasa hipotezinin başarısız olabileceğini dile getirmiştir (Sewell, 2011: 5). Ayrıca, etkin piyasalarda ödünç alanların ve ödünç verenlerin fırsatları eşittir. Ancak, gerçek dünyada farklı yatırımcılar gelecek hakkında farklı görüşlere sahiptirler ve beklenen getirileri belirlemek için farklı iktisadi modelleri kullanırlar. Farklılıklar nedeniyle fiyatlar, genel değerlerinden sürekli ve belirgin bir şekilde sapabilmektedir (Cuthbertson, 1997: 169).

Etkin piyasa hipotezine göre tarihsel ve güncel olarak mevcut tüm bilgiyi tamamen yansıtan finansal varlık fiyatları tüm yatırımcılarca aynı şekilde değerlendirildiği gibi gelecekteki fiyatların önyargısız tahminlerini de içeren tahmin edilebilir bilgi de piyasadaki tüm yatırımcılarca aynı şekilde değerlendirilmektedir. Hipotezin en uç şeklinde ise sadece kurum içinde çalışanlar ve kurumla ilgili olanlarca bilinen özel bilginin de fiyatlara yansıdığı öne sürülmektedir (Megginson, 1997: 131).

Fama (1970: 388), menkul kıymete yansıyan bilgi kümesini piyasa etkinliğinin derecesine göre, menkul kıymetin geçmiş fiyatlarına veya geçmiş getirilerine ilişkin bilgiler, kamuya açık tüm bilgiler ve herhangi bir yatırımcının veya grubun sahip olduğu tekelci bilgiler olmak üzere üç grupta toplamıştır. Literatürde, Fama (1970)'yı takiben etkinliğin zayıf, yarı güçlü ve güçlü olmak üzere üç formu bulunmaktadır.

Piyasada etkin piyasanın zayıf formu geçerli iken, fiyat değişimleri tamamen rastlantısaldır. Dolayısıyla, bir dönemdeki fiyat değişimleri istatistiki olarak diğer dönemdeki fiyat değişmelerinden bağımsızdır. Bu nedenle, geçmiş (tarihi) bilgiye dayanarak geliştirilen alım- satım kuralı ile hiçbir yatırımcının aşırı kar elde etmesi mümkün değildir. Kamuya menkul kıymetlerle ilgili bir bilgi açıklandığında fiyatlarda hızla ve açıklanan bilgiyi doğru değerlendiren bir fiyat ayarlaması meydana geldiğinde yarı güçlü etkin piyasa hipotezi geçerlidir. Güçlü etkin piyasa kuramında ise menkul kıymet fiyatlarının kamuya açıklanan ve açıklanmayan tüm bilgileri yansıttığı ileri sürülmektedir (Kıyılar, 1997: 17-55).

Zayıf form (weak form) etkin piyasa kuramı, fiyatların rassal yürüyüş (random walk) hipotezini test etmek için yapılan testleri kapsamaktadır (Iwatsubo ve Kitamura, 2008). Fama (1970: 384)'ya göre, menkul değerlere ilişkin oluşan denge fiyatlarını açıklamak için yapılan birçok çalışmanın dayandığı varsayım, piyasa denge koşulunun beklenen getiri ile ifade edilebileceği varsayımıdır. Piyasada oluşan denge beklenen getiriler, piyasada oluşan bilgiyi tamamen yansıtan bilgi setine dayanarak şekillenmiştir. Fama
(1970: 385), bu yüzden "adil oyunun (fair game)" menkul kıymetin beklenen getirisinin gerçekleşen getiriye eşit olduğunu göstermiştir.

Zayıf form etkinlikte, piyasada tüm fiyatlar, geçmiş fiyatlar veya getirilerde elde edilebilir (mevcut) tüm bilgiyi yansıtmaktadır (Wickremasinghe, 2004: 2). Burada, cari döviz kurlarının, geçmiş döviz kurlarında tüm mevcut bilgiyi yansıttığı iddia edilmektedir (Kühl, 2007: 6). Bu nedenle, bir spekülatör veya bir arbitrajcı gelecek döviz kurlarını öngörmek için geçmiş döviz kurlarını kullanamaz. Dolayısıyla, bunlar döviz işlemlerinden tutarlı kazançlar sağlamak için herhangi bir strateji izleyemez (Wickremasinghe, 2008: 43). Bu formda, cari fiyatın tamamen fiyatların tarihsel gelişiminde yer alan bilgiyi yansıttığı öngörülmektedir (Dowla, 1995: 95). Bir diğer ifadeyle, zayıf form etkinlikte, fiyatlar bilgiye ulaşmanın marjinal karları (yapılması beklenen karlar), onu toplamanın marjinal maliyetlerini aşmadığı noktaya kadar bilgiyi yansıtmalıdır (Beechey, Gruen ve Vickery, 2000: 2). Ancak, Berstein (1999), etkin piyasalar hipotezini eleştirmiş ve bilgiye yatırım yapan yatırımcıların marjinal karlarının marjinal maliyetlerini aştığını iddia etmiştir (Sewell, 2011: 6). Etkinliğin bu formunda, hiçbir yatırımcı tarihsel fiyatları kullanarak aşırı getiri elde edememektedir (Mehrara ve Oryare, 2012: 165).

Yarı güçlü form (semi-strong form) etkinlikte, döviz kurlarının sadece geçmiş döviz kurlarına ilişkin bilgiyi değil, aynı zamanda diğer döviz kurları ve makro ekonomik değişkenlere ilişkin bilgiyi de yansıttığı iddia edilmiştir. Bir spekülatör veya arbitrajcı, geçmiş döviz kurlarına ek olarak, bir döviz kurunu öngörmek için herhangi bir değişkenle ilgilenmek dışında döviz kurlarını kullanamaz. Dolayısıyla, bunlar döviz piyasasında kar elde etmek için herhangi bir kural veya teknikten yararlanamaz (Wickremasinghe, 2008: 44). Yarı güçlü form etkinlikte, kamuca elde edilebilir bilgiyi anlık olarak yansıtan finansal varlıkların fiyatları bulunmaktadır (Wickremasinghe, 2004: 2; Kühl, 2007: 6). Bir diğer ifadeyle, bu formda cari fiyatın tarihsel fiyat bilgisine ek olarak, tüm kamuca elde edilebilir bilgiyi açığa çıkardığı belirtilmektedir (Dowla, 1995: 95). Dolayısıyla, etkinliğin bu formunda, hiçbir yatıımcı tarihsel fiyatları ve kamuca elde edilebilir bilgiyi kullanarak aşırı getiri elde edememektedir (Mehrara ve Oryare, 2012: 165).

Son olarak, güçlü form (strong form) etkinlikte ise hiçbir yatırımcı tarihsel fiyatları içeren herhangi bir bilgiyi kullanarak fazla getiri elde edemez, bilgi kamuca elde edilebilir ve özel veya içsel bilgi bulunmaktadır (Mehrara ve Oryare, 2012: 165). Özel bilgi temelinde alım-satım daha yüksek karlar yaratmadığında piyasanın etkin olduğu söylenmektedir (Kühl, 2007: 
6)'. Ayrıca, tüm bilgi, maliyetsiz biçimde elde edilir ise güçlü etkinlikten bahsedilir. Bunun yerine, bilgiye ulaşılması maliyetli iken onun elde edilmesi için finansal bir teşvik olmalıdır. Ancak, bilgi zaten varlık fiyatlarında "tamamen yansıtılmış" ise bir finansal teşvik olmayacaktır (Grossman ve Stiglitz, 1980). Bu nedenle, etkin bir piyasada katılımcılar (i) bir finansal varlığın getirileri veya geçmiş fiyatlarını, (ii) kamuca elde edilebilir bilgiyi ve (iii) piyasayı tutarlı biçimde tahmin etmek için herhangi bir kuralı tasarlamada piyasanın içindekilerce (insiders) elde edilebilir bilgilerini kullanamazlar. Etkin piyasa hipotezinin (EMH) güçlü formu, hem zayıf hem de yarı güçlü etkinliklerini kapsamaktadır (Wickremasinghe, 2004: 2; Wickremasinghe, 2008: 44). Ayrıca, bu form, piyasanın herhangi bir piyasa katılımcısı tarafından bilinen tüm bilgiyi yansıttığını iddia etmektedir (Dowla, 1995: 95).

\subsection{Ampirik Literatür}

Fama (1965)'nın çalışmasından bu yana özellikle gelişmiş ülkelerde döviz piyasaları, yoğun biçimde farklı ekonometrik teknikler kullanılarak etkinlik yönünden test edilmiştir. Döviz piyasasının belirtilen formlarda etkinliğini ulusal ve uluslararası yazında farklı yöntemler kullanarak test eden çok sayıda çaIışma vardır. Bunlar arasında Lai ve Lai (1991), Rapp ve Sharma (1999), Wickremasinghe (2004), Ortiz vd. (2005), Giannellis ve Papadopoulos (2006), Kühl (2007), Allen ve Taco (2007), Kisaka vd. (2008), Azad (2009), Cheung, Su ve Choo (2011), İbrahim vd. (2011), Mehrara ve Oryare (2012), Ahmad, Rhee ve Wong (2012), Wong ve Ahmad (2013) uluslararası literatüre ilişkin çalışmalar iken, Türkiye için ise Akal, Birgili ve Durmuşkaya (2012) ile Çiçek (2014)'in çalışmaları bulunmaktadır.

Lai ve Lai (1991), beş temel para için aylık spot ve forward kurları dikkate alarak Temmuz, 1973-Aralık, 1989 döneminde birim kök ve eşbütünleşme testleri yardımıyla etkin piyasalar hipotezini test etmişler ve eşbütünleşmenin yokluğu hipotezini tüm paralar için reddettiklerinden döviz piyasasının etkinliğinin ihlalini ortaya koymuşlardır. Rapp ve Sharma (1999), ülkeler arasında ve ülke içinde spot ve forward döviz kuru piyasalarının etkinliğini, 1 Haziran, 1973-31 Aralık, 1996 döneminde altmış yedi ülke grubu için araştırmışlardır. Bu kurlar arasında uzun dönemli bir ilişkinin var olması etkin piyasalar hipotezini ihlal etmektedir. Çünkü, spot (forward) döviz kuru, diğer spot (forward) döviz kurunun bir fonksiyonu olarak öngörülebilmektedir. Sonuçlar, ülkeler arasında eşbütünleşme olmadığını ve dolayısıyla, döviz kurlarının piyasada etkin biçimde belirlendiğini göstermektedir. Wickremasinghe (2004), Ocak, 1986- Kasım, 2000 döneminde altı adet çift taraflı döviz kurlarını kullanarak Sri
Lanka'da döviz piyasasının zayıf ve yarı güçlü formlarda etkinliklerini test etmiştir. Sonuçlar, Sri Lanka döviz piyasasının etkin piyasalar hipotezinin zayıf formu ile tutarlı olduğunu gösterirken, yarı güçlü etkinliğin ise karşısında kanıt sunmaktadır.

Ortiz vd. (2005) on beş Latin Amerika ülkesi için 1970-2000 döneminde döviz kuru piyasalarının etkinliğini ampirik olarak araştırmışlar ve sonuçlar, hem zayıf döviz kuru politikalarından, hem de zayıf döviz kuru piyasası gelişmesinden kaynaklanan bölgede etkin olmayan döviz kuru piyasalarına işaret etmiştir. Giannellis ve Papadopoulos (2006) üç merkezi ve doğu Avrupa ülkesi için döviz piyasalarının etkinliğini 1991:1-2006:2 döneminde aylık veriler ile eşbütünleşme ve birim kök yöntemlerini kullanarak test etmişlerdir. Doğrusal birim kök testleri, polonya/euro ve çek/euro döviz piyasalarının zayıf formda etkin olduğunu, slovakya/euro döviz piyasasının ise yarı etkin olduğunu göstermiş̧tir.

Allen ve Taco (2007), ABD ve Japon paraları karşısında Avustralya dolarını kullanarak Ocak, 2003-Aralık, 2006 döneminde forward kur yansızlık hipotezini (FRUH) eşbütünleşme yoluyla test etmişlerdir. Sonuçlar, spot ve forward kurların eşbütünleşik olduğunu göstermiş olup ve FRUH ve piyasa etkinliği ile tutarlı çıkmıştır. Kühl (2007), euro'nun girişinden beri yedi en önemli döviz kurunda 4 Ocak, 1999-29 Aralık, 2006 döneminde döviz piyasasının etkinliğini eşbütünleşme yoluyla araştırarak döviz piyasalarının etkin olduğunu bulmuştur. Kisaka vd. (2008), Kenya için zayıf form etkin piyasa hipotezini birim kök testleri ve Ljung-Box Q istatistikleri kullanarak incelemişlerdir. Ocak, 1994-Haziran, 2007 döneminde Kenya şilininin (shilling) her bir ABD doları için günlük kapanış spot kuru ele alınmıştır. Sonuçlar, döviz piyasasını zayıf formda etkin olmadığını ortaya koymuştur.

Azad (2009) on iki Asya-Pasifik döviz piyasası için bireysel, panel birim kök testleri ve iki varyans oranı testini kullanarak rassal yürüyüş ve etkin piyasalar hipotezlerini test etmiştir. Çalışmanın dönem aralığı Ocak, 1998 - Haziran, 2007 olup Asya krizi sonrası günlük ve haftalık spot döviz kuru serileri kullanılmaktadır. Her iki frekansta her iki birim kök testi de tüm seriler için birim kökün varlığına işaret etmiştir. Diğer yandan, bireysel birim kök testleri ise on döviz kuru serisi için birim kökün varlığını tespit edebilmiş ve sonuçlar, zayıf form etkinliği desteklemiştir. Cheung, Su ve Choo (2011) seksen iki ülke için euro döviz piyasalarında piyasa etkinliğini test etmişlerdir. Bu amaçla 1999-2010 dönemi boyunca bu ülkelerin günlük döviz kuru getirilerinde otokorelasyon olup olmadığını bilinmeyen koşullu değişen varyans biçimlerine karşı dirençli olan üç yeni test kullanarak gerçekleştirmiş- 
lerdir. Altmış civarı ülke için döviz kuru getirilerinde anlamlı otokorelasyon tespit edilemediğinden çoğu euro döviz piyasalarının etkin olduğu bulunmuştur.

İbrahim vd. (2011) otuz OECD ülkesi için birim kök testlerini kullanarak 2000-2007 dönemi için haftalık veriler yardımı ile döviz piyasasının zayıf formda etkinliğini test etmişlerdir. Bu testler, döviz kurlarının rassal yürüyüş süreci izlediğine veya bir diğer ifadeyle, döviz kurunun bugünkü değerinin geçmiş değerleri kullanılarak tahmin edilemediğine işaret etmiştir. Ilave olarak, OECD döviz piyasası, zayıf form etkin piyasa hipotezi ile tutarlı görünmektedir. Mehrara ve Oryare (2012), 2007-2008 küresel ekonomik kriz sonrası döviz piyasasının etkinliğini beş para çifti için 12 Temmuz, 2002-9 Şubat, 2007 dönemi ile 16 Şubat, 2007-16 Eylül, 2011 dönemi olmak üzere iki ayrı dönemde değerlendirmişler ve döviz kurlarının tamamının getirileri, kriz öncesi bağımsız ve özdeş olarak dağılırken, kriz sonrasında dağılmadığı, yani etkin piyasa hipotezinin kriz öncesinde reddedilemezken, kriz sonrasında reddedilebildiğini bulmuşlardır. Ahmad, Rhee ve Wong (2012), Asya pasifik bölgesinin döviz piyasalarının genellikle eşbütünleşme tekniği kullanıldığında ülke içinde ve ülkeler arasında etkin olduğunu bulmuşlardır.

Wong ve Ahmad (2013), Avrupa döviz piyasalarının etkinliğini 1997-2012 döneminde hem ülke içi hem de ülkeler arası perspektiften araştırmış ve birkaç son krizi boyunca karşılaştırmıştır. Sonuçlar, bu piyasaların genellikle ülke içinde etkin olduğunu göstermiştir. Bir diğer ifadeyle, eşbütünleşme bulgusu, gelecek spot döviz kurlarının tahmincisi olarak forward kurların yansızlığına işaret etmektedir. Ülkeler arası piyasa etkinliğinde ise eşbütünleşme bulgusu, bir döviz kurundan diğer döviz kurunun öngörülebilirliğine işaret ettiği için piyasa etkinliğinde bozulmaya neden olmaktadır. Türkiye ile ilgili çalışmalara bakıldığında ise Akal, Birgili ve Durmuşkaya (2012) ABD doları ve Euro döviz piyasalarının etkin olup olmadığını 20052012 döneminde günlük veri seti kullanarak test etmişler ve bu piyasaların zayıf formda etkin olmadığını bulmuşlardır. Çiçek (2014), Türkiye'de 5 Şubat, 2005-26 Temmuz, 2013 döneminde eşbütünleşme yöntemini kullanarak TL/dolar ve TL/Euro döviz piyasalarının etkinliğini araştırmış ve bu piyasaların zayıf ve yarı güçlü formda etkin olduğunu bulmuştur.

\section{MODEL}

Hisse senedi ve döviz piyasalarında etkin piyasa hipotezi ile ilgili ampirik çalışmaların çoğunda, ABD hisse senedi piyasası ve ABD doları karşısında döviz kurlarına ilişkin veriler kullanılmıştır. ABD piyasaları, belki de dünyadaki en derin ve en rekabetçi finan- sal piyasaları olduğu için etkin piyasa hipotezini test etmenin makul bir zeminini sağlamaktadır (Beechey, Gruen ve Vickery, 2000). Diğer yandan, Euro'nun ortaya çıkışı, uluslararası finans literatüründe önemli gelişmelerden biri olup 1999 yılından bu yana, Euro, $A B D$ dolarından sonra ikinci en çok kullanılan uluslararası para birimidir (Cheung, Su ve Choo, 2011). Bu nedenlerle, bu çalışmada, hem ABD doları hem de Euro karşısında TL'nin davranışı analiz edilmektedir. Çalışmanın mevcut literatüre temel katkısı, Türkiye'de konuyla ilgili yapılan çalışmaların oldukça sınırlı olması ve diğer çalışmalardan farklı olarak, döviz piyasasının etkinliğinin "yapısal kırımalı" birim kök ve eş bütünleşme yöntemleri ile test edilerek bir ilki oluşturmasıdır. Dolayısıyla, çalışmanın temel hipotezleri "Türk döviz piyasası zayıf ve yarı güçlü formlarda etkin midir? ve bu piyasada "forward kur yansızlık hipotezi" (FRUH) geçerli midir? şeklindedir.

Ülkeler arasında döviz piyasası etkinliğini test etmek için çok sayıda araştırmacı (MacDonald ve Taylor, 1989), Coleman (1990), Hakkio ve Rush (1989), Copeland (1991), Sephton ve Larsen (1991), Baillie ve Bollerslev (1994)) spot döviz kurlarına eşbütünleşme yöntemini uygulamıştır. Spot döviz kurları eşbütünleşik iken seriler en azından bir yönde nedensel bir sıralama ile ifade edilebilmektedir. Çalışmalar, kullandıkları zaman dönemine, döviz kurlarının seçimine ve metodolojiye bağlı olarak, spot döviz kurları için etkin piyasalar hipotezinin reddinde farklılaşmışlardır (Rapp ve Sharma, 1999: 424).

Fama (1970)'nın çalışmasından beri, etkin piyasa hipotezi, özellikle gelişmiş ülkelerde uygulanmaya başlamıştır. Bu ülkelerde döviz piyasaları, genellikle farklı ekonometrik teknikler kullanılarak etkinlik testlerine tabi tutulmuştur. Bu tekniklerin amaçları (i) bir para için spot döviz kurunun rassal yürüyüş (random walk) şeklinde davranıp davranmadığını; (ii) bir para için forward kurun o para için gelecek spot döviz kurunun yansız bir tahmincisi (FRUH) olup olmadığını ve (iii) birkaç para arasında eşbütünleşme ilişkisinin var olup olmadığı şeklinde karşımıza çıkmaktadır. Testlerin ilk türü, zayıf form etkinlik testleri iken ikinci ve üçüncü türleri ise yarı güçlü form etkinliktir (Wickremasinghe, 2008: 45). Bir diğer ifadeyle, zayıf form etkinlik, birim kök testleri kullanılarak incelenirken, yarı güçlü form etkinlik ise genellikle eşbütünleşme analizi kullanılarak test edilmektedir (Wickremasinghe, 2008: 2). Bu çalışmada belirtilen türler üzerinde durulmaktadır.

Döviz piyasalarının etkinliğinin araştııımasında kullanılan testlerden en popüler olanı spot ve forward kurlar arasındaki ilişkinin analizidir. Bilgisel olarak etkin bir piyasada, forward döviz kuru, gelecek spot 
döviz kurlarının yansız bir tahmincisi olmalıdır. Bu ilişkinin arkasındaki mevcut teori, örtüsüz (uncovered, UIP) faiz paritesidir. UIP teorisi altında paranın diğerine faiz oranı avantajının iki para arasında faiz farkı oldukça benzer olarak döviz kurunda zıt bir hareket şeklinde dengelenmesi beklenmektedir. Örtülü (covered) faiz oranı paritesinde ise iki para arasında faiz farkı, belli para çiftlerinin spot ve forward döviz kurları arasındaki farkta yansıtılmaktadır (Wong ve Ahmad, 2013: 2). Bu "forward prim" olarak da bilinmektedir. Bu nedenle, döviz piyasasının etkinliği büyük ölçüde spot döviz kurundaki değişmelerin karşıllık gelen gecikmeli forward prime regresyonunun yapılmasıyla test edilmektedir. 1980'li yılların sonlarından beri, piyasa etkinliğini incelemek için eşbütünleşme tekniği de spot ve forward döviz kurları arasındaki ilişkinin test edilmesinde kullanılmaya başlanmıştır (Wong ve Ahmad, 2013: 3).

Döviz piyasalarının etkinliği "ülke içinde" (within country) ve "ülkeler arasında" (across country) perspektiflerden de görülebilmektedir. Döviz piyasasında, ülke içi perspektiften forward döviz kurları, gelecek spot döviz kurlarının yansız bir tahmincisi ise bu piyasa ülke içinde etkindir. Eğer forward kur, yansız bir tahminci olarak başarısız ise bir kar fırsatı elde edilebilir ve fazla getiriler mümkün hale gelmektedir. Ülkeler arası etkin bir piyasada ise bir ülkenin spot döviz kurları diğer ülkenin spot döviz kurlarıyla tahmin edilebilir olmamalıdır. Farklı ülkelerin spot döviz kurlarının serileri arasında eşbütünleşmenin varlığı ülkeler arasında piyasa etkinliğinin ihlalini göstermektedir (Ahmad, Rhee ve Wong, 2012: 1578). Bu çalışmada Türkiye'de piyasa etkinliği ülke içi perspektiften belli para çiftlerinin spot ve forward döviz kurları arasındaki ilişkisine bakılmaktadır. Örtüsüz (uncovered) faiz paritesi teorisine dayanarak forward döviz kuru gelecek spot döviz kurunun yansız bir tahmincisi olmalıdır ve bu ilişkiden herhangi bir sapma, piyasa etkinliğinin bir ihlalini göstermektedir. Bu koşul, "forward yansızlık hipotezi" (forward unbiasedness hypothesis, FRUH) olarak bilinmektedir (Wong ve Ahmad, 2013: 2).

Forward piyasalarının etkinliği sıklıkla aşağıdaki modele dayanmaktadır:

$$
S_{t}=a+b F_{t-1, t}+\varepsilon_{t}
$$

burada $S_{t}$ tzamanında spot fiyatı, $F_{t-1, t}$ tzamanında vadesi gelen forward sözleşme için $t-l$ zamanındaki fiyattır. $\varepsilon_{t}$ sıfır ortalama ve sonlu varyanslı bir hata terimidir. Modelde $a$ ve $b$ sabit katsayılardır. Spot döviz kurlarındaki değişmelerin gecikmeli forward prime regresyonu "Fama regresyonu" olarak bilinmektedir. Gelecek spot döviz kurlarını öngörmede forward döviz kurlarının yanlııı̆ı kalııı bir olgu olmaya başla- mış ve bu "forward yanlılık bulmacası" olarak adlandırılmıştır (Wong ve Ahmad, 2013: 3). Piyasa etkinliği hipotezi altında piyasa fiyatı, alım-satım yapanların tutarlı biçimde spot fiyatın gelecek düzeylerinde forward piyasada spekülasyon yaparak kar sağlayabilecekleri hiçbir stratejinin var olmaması için tamamen mevcut bilgiyi yansıtmalıdır. Etkinlik, modelde $a=0$ ve $b=1$ test edilebilir kısıta işaret etmekte, bu ise "yansızlık" hipotezi olarak ifade edilmektedir (Lai ve Lai, 1991: 567). Her iki değişken eşbütünleşik değil ise $F_{t-1, t^{\prime}} S_{t}$ 'nin hareketine ilişkin çok az öngörü gücüne sahiptir ve bu ise açıkça piyasa etkinliği hipotezi ile tutarsızdır (Lai ve Lai, 1991: 569). Bir diğer ifadeyle, bu kısıt doğru ise piyasa etkinliği desteklenmektedir (Rapp ve Sharma, 1999: 427).

Etkin piyasalar hipotezinde döviz kurlarının tutarlı biçimde rassal yürüyüş şeklinde davranıp davranmadığı da incelenmektedir. Bir diğer ifadeyle, döviz kurunun gelecek değerinin, geçmiş değerleri kullanılarak öngörülüp öngörülemeyeceği test edilmektedir. Eğer döviz kurunun gelecek değeri, geçmiş değerleriyle öngörülebiliyor ise bu tür bir döviz kurunun davranışı, EMH'nin zayıf formu ile tutarlı değildir. Döviz kuru rassal bir yürüyüş süreci izler iken döviz kurları birinci farklarında durağan olmalıdır (Wickremasinghe, 2008: 47).

\section{VERI VE METODOLOJi}

Çalışmada Türkiye'de döviz piyasasının etkinliğini test etmek üzere 2006:04-2013:12 dönemi için (93 gözlem) TL'nin Euro ve dolara karşı aylık spot ve forward döviz kurları kullanıımıştır. Dönem aralığı forward kura ait verinin elde edilebilirliği ile sınırlandırılmıştır. Döviz piyasasının etkinliği hem TL/\$, hem de TL/Euro döviz kurları için sınanmıştır. Spot ve forward kurlar doğal logaritmaları alınarak analize dahil edilmiştir. Spot kura ait veri Lai ve Lai (1991)'nin çalışmasını takiben dövizin alış kuru olarak Türkiye Cumhuriyet Merkez Bankası Elektronik Veri Dağıtım Sisteminden (EVDS) ve bir aylık forward kur ise datastream veri tabanından temin edilmiştir.

Çalışmada zayıf form etkinliği test etmek için geleneksel ve yapısal kırılmaları dikkate alan birim kök testleri uygulanmaktadır. Daha sonra aylık spot ve forward döviz kurlarının birinci farklarında durağan çıkması [I(1)] halinde eşbütünleşme analizi yapılmakta; eşbütünleşmenin varlığı durumunda uzun dönemli ilişkiyi veren vektör, tamamen değiştirilmiş EKK

(FMOLS) yöntemiyle tahmin edilmekte ve $a_{0}=0$ ve $\beta=1$ şeklindeki FRUH hipotezi test edilmektedir. 


\subsection{Birim Kök Analizi}

Geleneksel birim kök testlerinde küçük örneklem sapması nedeniyle sorun oluşmaktadır. Bu testlerin durağanlık (stationary) yönünde kanıt elde edememelerinin temel nedenlerinden biri yapısal kırılmaları dikkate almamaları iken, zaman serilerinin çoğu, çoklu yapısal kırılmalardan etkilenmektedir. Literatürde geleneksel birim kök testlerinin zayıflı̆ı nedeniyle iki yönde gelişme olmuştur. Bunlardan ilki, hem yatay kesit, hem de zaman serisi boyutuna ait bilgiyi içeren panel birim kök testlerinin kullanılmasıdır. İkincisi ise yapısal kırılmaları dikkate alan birim kök testlerinin uygulanmasıdır. Perron (1989)'a göre serilerde yapısal kırılma mevcut iken durağanlık şeklindeki alternatif hipotez doğru kabul edilip yapısal kırılmalar ihmal edildiğinde birim kök hipotezinin reddedilme gücü azalmaktadır. Böylece, araştırmacılar birim kök sürecine yapısal kırılmaları da dahil etmeye başlamışlardır. Örneğin, Zivot ve Andrews (1992, ZA testi) içsel tek kırılmalı birim kök testini; Lumsdaine ve Papell (1997, LP testi) ise ZA testini içsel olarak iki kırılmaya izin verecek şekilde geliştirmiştir. Ancak, ZA ve LP testlerinin en önemli eksiklikleri, birim kökün varlığı şeklindeki boş hipotez altında kırılma varsaymayıp kritik değerlerini ise bu duruma uygun olarak türetmeleridir. Bu sorunu gidermek için Lee ve Strazicich $(2003,2004)$ LM birim kök testlerini geliştirmişler ve böylece, bu çalışmada da LM birim kök testleri kullanılmıştır.

LM birim kök testinde kırılma anları içsel olarak belirlenmekte ve bu nedenle test kırılmalarla birlikte birim kökün varlığı halinde sahte reddetmelere konu olmamaktadır. En önemlisi ise alternatif hipotezin doğru olması durumunda sahte reddetmelere konu değildir (Lee ve Strazicich, 2004: 2). LM testinde sıfır hipotezinin reddi zorunlu olarak birim kökün değil kırılmalar olmaksızın birim kökün reddine işaret etmektedir (Lee ve Chang, 2008: 316).

Geleneksel birim kök sürecine dayalı ADF gibi yapısal kırılmalı birim kök testlerinin aksine LM birim kök testinde yapısal kırılmalara sıfır hipotezi altında da izin verilmektedir. LM birim kök testinde yapısal kırılmalar Perron (1989)'a dayalı olarak modellenmekte ve (2) nolu veri oluşturma süreci ile açıklanmaktadır:

$$
y_{t}=\delta^{\prime} Z_{t}+X_{t} t, X_{t}=\beta X_{t-1}+\varepsilon_{t}
$$

Bu çalışmada $y_{t}$ spot ya da forward kuru, $Z_{t}$ ise dışsal (egzojen) değişkenleri, $\varepsilon_{t}$ ise klasik özelliklere sahip hata terimini temsil etmektedir. Sadece düzeyde iki kırılmaya izin veren Model A dikkate alındığın-

da $Z_{t} \quad\left[1, t, D_{1, t}, D_{2, t}\right]^{\prime}$ şeklindedir. $D_{j, t}$ serinin düzeyinde kırılmalara izin veren gölge değişkendir. $T_{B j}$ 'nin iki kırılmaya ilişkin tarihi göstermesi duru- munda $t \geq T_{B j}+1$ için $D_{j, t}=1$ ve diğer durumlarda ise $0^{\prime}$ dır ( $j=1,2$ iken). Serinin düzeyinde ve eğiminde iki kırılmaya izin veren Model $C$ dikkate alındığında ise $\quad Z_{t}\left[1, t, D_{1, t}, D_{2, t}, D T_{1, t}, D T_{2, t}\right]^{\prime}$ şeklindedir. Burada $D_{j, t}$ ve $D T_{j, t}$ sırasıyla serinin düzeyinde ve eğiminde yapısal kırılmaları temsil eden gölge değişkenlerdir. $t \geq T_{B j}+1$ için $D_{j t}=1$, aksi halde 0 'a eşittir. Ayrıca $t \geq T_{B j}+1$ için, $D T_{j t}=t-T_{B j}$ aksi halde 0 'a eşittir ( $j=1,2$ iken). Veri oluşturma süreci ise sıfır hipotezi ( $\beta=1$ ) ve alternatif hipotez ( $\beta \prec 1$ ) altında kırılmaları içermektedir. Model A ve C'de $\beta$ 'nın değerine bağlı olarak sıfır ve alternatif hipotezler (3) ve (4) nolu denklemler ile temsil edilmektedir:

Sıfır: $y_{t}=c_{o}+d_{1} B_{1 t}+d_{2} B_{2 t}+y_{t-1}+v_{1 t}$ (Model A)

Alternatif: $y_{t}=c_{1}+\gamma t+d_{1} D_{1 t}+d_{2} D_{2 t}+v_{2 t}$ SIfIr: $y_{t}=c_{o}+d_{1} B_{1 t}+d_{2} B_{2 t}+y_{t-1}+v_{1 t}$

(Model C) (4)

Alternatif:

$$
\begin{aligned}
y_{t}= & c_{1}+\gamma t+d_{1} D_{1 t}+d_{2} D_{2 t} \\
& +d_{3} D T_{3 t}+d_{4} D T_{4 t}+v_{2 t}
\end{aligned}
$$

Denklemlerdeki $v_{j t}$ durağan hata terimini, $B_{j t}$ sıfır hipotezi altındaki gölge değişkeni temsil etmekte olup $t=T_{B j}+1$ için $B_{j t}=1$, aksi halde 0'a eşittir ( $\mathrm{j}=1,2$ iken). Ayrıca, LM testinde birim kök test istatistiği (5) nolu regresyondan elde edilmektedir.

$$
\Delta y_{t}=\delta^{\prime} \Delta Z_{t}+\varphi \widetilde{S}_{t-1}+\sum_{p=1}^{k} B_{p} \Delta \widetilde{S}_{t-p}+\varepsilon_{t}
$$

$\Delta y_{t}$ ve $\Delta Z_{t}$ sırasılyla $y_{t}$ ve $Z_{t}$ 'nin ilk fark değerleridir. $y_{t}$ 'nin trendden arındırılmış değeri $\widetilde{S}_{t-1}$ ile temsil edilmektedir. Otokorelasyonu düzeltmek için $\Delta \widetilde{S}_{t-p}$ ADF tipi birim kök testlerinde olduğu üzere regresyona dahil edilmektedir. $\varepsilon_{t}$ klasik varsayımları içeren stokastik hata terimidir. $y_{t}$ 'nin durağanlığı $\left(H_{0}=\varphi=0\right)$ şeklindeki hipotez ile sınanmaktadır. Nihai olarak ise (4) nolu regresyonda $\varphi=0$ için geliştirilen $\mathrm{t}$ testi her ülke için LM test istatistiğini $(\tilde{\tau}$ ) hesaplamak için kullanılmaktadır (Lee ve Strazicich, 2003, 2004). 


\subsection{MAKi (2012) Eşbütünleşme Testi}

Eşbütünleşme testleri ile incelenen iktisadi değişkenler arasındaki denge ilişkisi genellikle yapısal kırılmalara sahiptir. Söz konusu yapısal kırılmalar, politik değişiklikler, iktisadi ajanların davranışı ve bazı şoklar nedeniyle ortaya çıkmaktadır. Eşbütünleşme ilişkisindekiyapısal kırılmalareşbütünleşmetestlerinin performansını anlamlı bir şekilde etkilemektedir (Maki, 2012). Engle ve Granger (1987) ve Johansen $(1988,1991)$ gibi geleneksel eşbütünleşme testleri, yapısal kırımaların varlığı durumunda kötü bir performans sergilemektedir (Gregory vd., 1996). Bu nedenle geleneksel eşbütünleşme testleri, yapısal kırılmalar altında yeterince eşbütünleşme ilişkisi bulamamaktadır. Bu sorunun ortadan kaldırılması için Gregory ve Hansen (1996a, b) eşbütünleşme vektöründe tek kırılmaya izin veren, Hatemi-J (2008) ise iki kırılmaya izin veren eşbütünleşme testleri geliştirmişlerdir. Ancak, Maki (2012) araştırmacıların genellikle kırılma sayısı hakkında önsel bir bilgiye sahip olmadıklarını dile getirmiştir. Doğru kırılma sayısı bir iken Hatemi-J (2008)'ye ait test kötü bir performans sergilerken, doğru kırılma sayısı iki iken ise Gregory ve Hansen (1996a, b)'e ait eşbütünleşme testleri kötü bir performans göstermektedir. Doğru kırılma sayısının üçten fazla olması halinde ise bahsedilen her iki test de kötü performansa sahiptir. Bu nedenle, eşbütünleşme testlerinde belirlenmemiş sayıda kırılma dikkate almak arzulanmaktadır. Böyle bir test geleneksel eşbütünleşme testlerinden daha iyi bir performansa sahiptir.

Maki (2012)'nin testi hata terimi (kalıntı) temelli bir model olup eşbütünleşme vektörünün belirlenmemiş olan kırılma sayısının, maksimum kırılma sayısına eşit ya da daha az olduğunu varsaymaktadır. $\mathrm{Bu}$ yöntem, sadece belirlenmemiş sayıda kırılmayı dikkate almamakta, aynı zamanda literatürde yaygın olarak kullanılan diğer yöntemlere kıyasla hesaplama açısından daha az yoğun ve karmaşıktır. Test, Bai ve Perron (1998) tarafından önerilen yapısal kırılma testi ile Kapetanios (2005) tarafından geliştirilen birim kök testine dayalıdır. Monte-Carlo simülasyonları, eşbütünleşme ilişkisinin çoklu kırılmaya ya da devamlı Markov rejim kaymasına sahip olması durumunda, söz konusu testin Gregory ve Hansen (1996a, b) ve Hatemi-J (2008)'ye kıyasla daha iyi performans gösterdiklerini ortaya koymuştur. Testin temel aldığı dört model söz konusudur:

$$
\begin{aligned}
& y_{t}=\mu+\sum_{i=1}^{k} \mu_{i} D_{i, t}+\beta^{\prime} x_{t}+u_{t,} \\
& y_{t}=\mu+\sum_{i=1}^{k} \mu_{i} D_{i, t}+\beta^{\prime} x_{t}+\sum_{i=1}^{k} \beta_{i}^{\prime} x_{t} D_{i, t}+u_{t},
\end{aligned}
$$

$$
\begin{gathered}
y_{t}=\mu+\sum_{i=1}^{k} \mu_{i} D_{i, t}+\gamma_{t}+\beta^{\prime} x_{t}+\sum_{i=1}^{k} \beta_{i}^{\prime} x_{t} D_{i, t}+u_{t}, \\
y_{t}=\mu+\sum_{i=1}^{k} \mu_{i} D_{i, t}+\gamma t+\sum_{i=1}^{k} \gamma_{i} t D_{i, t}+\beta^{\prime} x_{t} \\
+\sum_{i=1}^{k} \beta_{i}^{\prime} x_{t} D_{i, t}+u_{t},
\end{gathered}
$$

Burada $t=1,2, \ldots . ., T . y_{t}$ ve $x_{t}=\left(x_{1 t}, \ldots . . x_{m}\right)^{\prime}$ gözlenebilir I(1) değişkenleri temsil etmektedirler. $u_{t}$, denge hatası iken $y_{t}$ bir skalardır $x_{t}=\left(x_{1 t}, \ldots . . x_{m t}\right)^{\prime}$ ve ise $(m \times 1)$ boyutlu bir vektördür. ( $\mathrm{n} \times 1)$ boyutundaki $z_{t}$ vektörü $z_{t}=\left(y_{t}, x_{t^{\prime}}^{\prime}\right)^{\prime}=z_{t-1}+\varepsilon_{t}$ şeklinde türetilmektedir ki burada $\varepsilon_{t}$ bağımsız ve özdeş (i.i.d) dağılıma sahiptir, sıfır ortalama ve pozitif tanımIı varyans-kovaryans matrisi $\left(\sum\right)$ ile. $\left.\left.E\right|_{t}\right|^{s} \prec \infty$ , bazı s $>4$ için. $\mu, \mu_{i}, \gamma, \gamma_{i}, \beta^{\prime}=\left(\beta_{i}, \ldots . ., \beta_{m}\right)$ ve $\beta_{i}^{\prime}=\left(\beta_{i 1} \ldots \ldots \beta_{i m}\right)$ doğru parametrelerdir. $t \succ T_{B i}(i=1, \ldots . ., k)$ durumu için $D_{i, t}=1$ aksi halde 0 'a eşittir. $k$ maksimum kırılma sayısını ve $T_{B i}$ ise kırılma zamanını göstermektedir. (6) nolu denklem, düzeyde değişime izin vermektedir. (7) nolu denklem rejim değişim modeli olarak adlandırılmakta, $\mu$ 'ya ilave olarak $\beta^{\prime}$ ' ın da kırılmasına izin vermektedir. (8) nolu denklem (7) nolu denklemin trendli halini temsil etmektedir. (9) nolu denklem ise düzeyde, trendde ve regresörler de kırılmalara izin vermektedir.

Testin sıfır hipotezi eşbütünleşme yoktur şeklinde iken, alternatif hipotezi ise kırılma ile $(i \leq k)$ eşbütünleşmenin varlığına işaret etmektedir. Test, kırımanın olmadığı durumları ya da ardıl yıllarda meydana gelen kırılma durumlarını ortadan kaldırabilmek için her bir kırılma için trimaj parametresi $(\eta=0.005)$ kullanmaktadır. Örneğin, kırılma sayısı $(m=2)$ iken ilk kırılma anı örneklem boyutunun (T) \%5'i ile \%95'i arasında olacak şekilde tahmin edilmektedir. Testin kritik değerleri ise, modele, regresör sayısına, maksimum kırılma sayısına $(k)$ ve trimaj parametresine $(\eta)$ bağlı olarak değişmektedir. Maki (2012), maksimum 5 ( $k=5$ ) kırılma sayısına ve 4 açıklayıcı değişkene $(R V=4)$ kadar kritik değerleri türetmiştir.

\subsection{FMOLS Tahmini}

Eşbütünleşme vektörünün tahmini için Phillips ve Hansen (1990) tarafından geliştirilen tamamen değiştirilmiş EKK (FMOLS) tahmincisinden faydalanılmıştır. FMOLS, klasik EKK tahmincisinde iki düzeltme yapılarak elde edilmektedir. Bir diğer ifade ile PhillipsHansen (1990) EKK tahmincisindeki sapmayı ve içsel- 
liği düzelterek FMOLS tahmincisini elde etmişlerdir. FMOLS'un küçük örneklemlerde de iyi performans gösterdiği tespit edilmiştir. FMOLS'i açıklayabilmek için (10) nolu denklem ele alındığında:

$$
y_{t}=\beta_{0}+\beta^{\prime} x_{t}+u_{t}
$$

$y_{t}$ bağımlı değişkene ait vektörü, $x_{t}$ ise $(\mathrm{kx} 1)$ boyutunda bağımsız değişkenlerin bir vektörüdür. $y_{t}$ ve $x_{t}$ 'nin her ikisinin de I(1) olduğu kabul edilmektedir. $\Delta x_{t}=\mu+w_{t}$ şeklinde ifade edilmekte olup $\mu(\mathrm{kx} 1)$ boyutunda eğim parametrelerinin bir vektörünü, $w_{t}$ ise $(\mathrm{kx} 1)$ boyutunda durağan değişkenlerin bir vektörüdür. $u_{t}$ ve $w_{t}$ 'nin tutarlı tahminleri $\hat{\xi}=\left(\hat{u}_{t}, \hat{w}_{t}\right)^{\prime}$ şeklinde tanımlanmaktadır.
FMOLS'dan elde edilen hata terimi durağan ise (10) nolu denklemdeki bağımlı ve bağımsız değişkenler eşbütünleşiktir (Phillips ve Hansen, 1990).

\section{AMPIRIKK SONUÇLAR}

\subsection{Birim Kök ve Zayıf Dışsalık Testleri}

Başlangıç aşaması olarak ve LM birim kök testleri ile kıyaslamak için kırılmaları dikkate almayan geleneksel zaman serisi birim kök testlerinden genişletilmiş Dickey-Fuller (ADF, 1979) ve Phillips ve Perron (PP, 1988) testleri spot ve forward döviz kurlarına uygulanmış ve sonuçlar Tablo 1'de sunulmuştur. Ayrıca çalışmadaki verilerin düzey değerlerine ilişkin grafikler ise Şekil 1 ve Şekil 2'de gösterilmiştir².
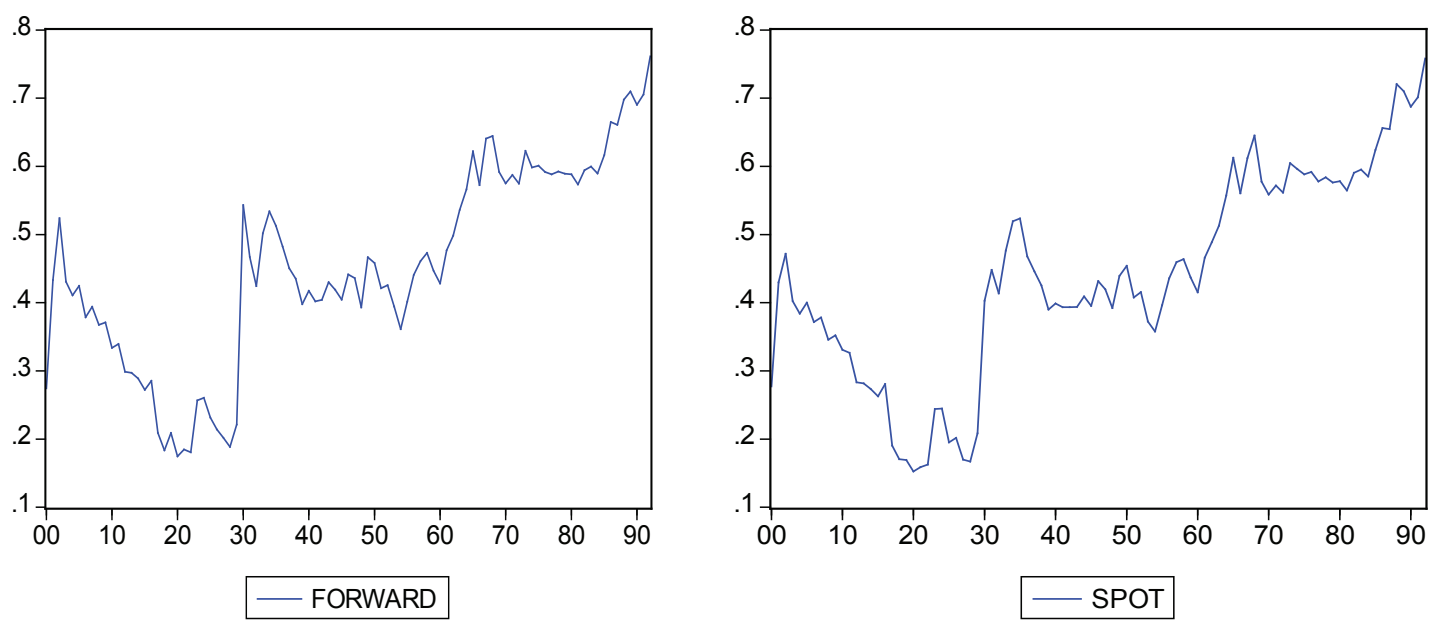

Şekil 1: TL/\$ Forward ve Spot Döviz Kurları
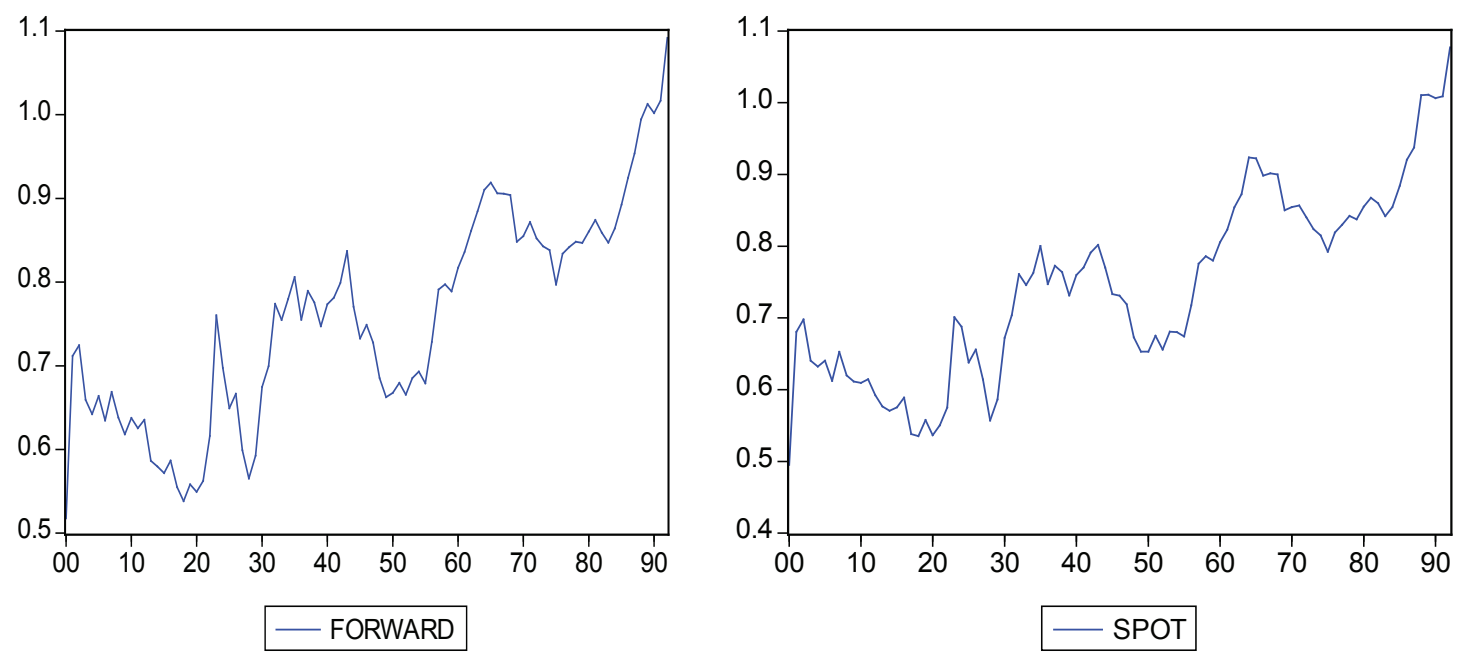

Şekil 2: TL/Euro Forward ve Spot Döviz Kurları

Şekil 1 ve 2'de görüldüğü üzere, dolar ve Euro'nun forward ve spot kurları yukarıya doğru (pozitif) bir trend izlemekte ve serilerin düzey ve eğimlerinde kırılmaların olduğu dikkati çekmektedir. 
Tablo 1: ADF ve PP Birim Kök Test Sonuçları

\begin{tabular}{|c|c|c|c|}
\hline \multicolumn{2}{|c|}{$\begin{array}{l}\text { FORWARD TL/\$ } \\
\text { (DÜZEY) }\end{array}$} & \multicolumn{2}{|c|}{$\begin{array}{l}\text { SPOT TL/\$ } \\
\text { (DÜZEY) }\end{array}$} \\
\hline ADF & PP & ADF & PP \\
\hline $\begin{array}{c}-2.712 \\
(0.2342)\end{array}$ & $\begin{array}{l}-2.629 \\
(0.268)\end{array}$ & $\begin{array}{l}-2.144 \\
(0.514)\end{array}$ & $\begin{array}{l}-2.268 \\
(0.446)\end{array}$ \\
\hline \multicolumn{2}{|c|}{$\begin{array}{l}\text { FORWARD TL/\$ } \\
\text { (FARK) }\end{array}$} & \multicolumn{2}{|c|}{$\begin{array}{l}\text { SPOT TL/\$ } \\
\text { (FARK) }\end{array}$} \\
\hline ADF & PP & ADF & PP \\
\hline $\begin{array}{c}-10.460^{* * * * *} \\
(0.000)\end{array}$ & $\begin{array}{c}-10.460^{* * * *} \\
(0.000)\end{array}$ & $\begin{array}{l}-9.065^{* * *} \\
(0.000)\end{array}$ & $\begin{array}{c}-9.068^{* * *} \\
(0.000)\end{array}$ \\
\hline \multicolumn{2}{|c|}{$\begin{array}{l}\text { FORWARD TL/Euro } \\
\text { (DÜZEY) }\end{array}$} & \multicolumn{2}{|c|}{$\begin{array}{l}\text { SPOT TL/Euro } \\
\text { (DÜZEY) }\end{array}$} \\
\hline ADF & PP & ADF & PP \\
\hline $\begin{array}{l}-2.582 \\
(0.289)\end{array}$ & $\begin{array}{l}-2.893 \\
(0.169)\end{array}$ & $\begin{array}{l}-2.440 \\
(0.356)\end{array}$ & $\begin{array}{l}-2.796 \\
(0.202)\end{array}$ \\
\hline \multicolumn{2}{|c|}{$\begin{array}{l}\text { FORWARD TL/Euro } \\
\text { (FARK) }\end{array}$} & \multicolumn{2}{|c|}{$\begin{array}{l}\text { SPOT TL/Euro } \\
\text { (FARK) }\end{array}$} \\
\hline $\begin{array}{l}-10.090^{* * * *} \\
(0.000)\end{array}$ & $\begin{array}{c}-10.113^{* * * *} \\
(0.000)\end{array}$ & $\begin{array}{l}-9.897^{* * * *} \\
(0.000)\end{array}$ & $\begin{array}{l}-9.937^{* * * *} \\
(0.000)\end{array}$ \\
\hline
\end{tabular}

( Not: ADF birim kök testinde gecikme uzunlukları Schwarz bilgi kriterine (SIC) göre belirlenmiştir. PP testinde spektral tahmin methodu olarak Bartlett-kernel ve bant seçiminde ise NeweyWesttercih edilmiştir. Birim kök testi sabitli ve trendli model üzerinde yapılmıştır. Parantez içerisindekiler olasılık değerlerini göstermektedir)

Tablo 1'de görüldüğü üzere, Forward TL/\$, Spot $\mathrm{TL} / \$$, Forward TL/Euro ve Spot TL/Euro serileri birinci farklarında durağandır [ı(1)]. Dolayısıyla, bu kurlar zayıf form etkinlik ile tutarlı bir biçimde rassal bir yürüyüş süreci izlemektedir. Bu anlamda döviz kurunun geçmiş değerleri, döviz kurunun gelecek döneme ait değerlerinin tahmininde kullanılamamaktadır. Sonuç olarak, döviz kuru piyasasının katılımcıları sürekli biçimde alım-satım yaparak kazanç elde etmek için herhangi bir istatistiki teknik izleyemezler (Çiçek, 2014). Tablo 2 ise iki kırılmanın dikkate alındığı LM birim kök testi sonuçlarını göstermektedir. 
Tablo 2: LM Birim Kök Testi Sonuçları

\begin{tabular}{|c|c|c|c|c|}
\hline & DÜZEY & FARK & DÜZEY & FARK \\
\hline \multicolumn{2}{|c|}{ FORWARD(TL/\$) } & FORWARD(TL/\$) & SPOT(TL/\$) & SPOT (TL/\$) \\
\hline$\tilde{\tau}$ & -5.0528 & $-9.7398^{* * *}$ & -4.573 & $-7.926^{* * *}$ \\
\hline$\varphi$ & -0.4780 & -1.1070 & -0.443 & 0.905 \\
\hline$T_{B j}$ & $\begin{array}{l}\text { 2008:08 } \\
\text { 2009:05 }\end{array}$ & $\begin{array}{l}\text { 2007:10 } \\
\text { 2011:08 }\end{array}$ & $\begin{array}{l}\text { 2008:08 } \\
\text { 2010:01 }\end{array}$ & $\begin{array}{l}\text { 2007:10 } \\
\text { 2012:04 }\end{array}$ \\
\hline \multirow[t]{3}{*}{ k } & 0 & 0 & 7 & 0 \\
\hline & DÜZEY & FARK & DÜZEY & FARK \\
\hline & FORWARD(TL/Euro) & FORWARD(TL/Euro) & SPOT(TL/Euro) & SPOT (TL/Euro) \\
\hline$\tilde{\tau}$ & -4.1391 & $-7.9773^{* * *}$ & -4.4921 & $-7.4951^{* * *}$ \\
\hline$\varphi$ & -0.3408 & -0.8940 & -0.3280 & -0.8477 \\
\hline$T_{B j}$ & $\begin{array}{l}\text { 2008:07 } \\
\text { 2009:10 }\end{array}$ & $\begin{array}{l}\text { 2007:09 } \\
\text { 2009:09 }\end{array}$ & $\begin{array}{l}\text { 2008:06 } \\
\text { 2009:10 }\end{array}$ & $\begin{array}{l}\text { 2007:09 } \\
\text { 2011:06 }\end{array}$ \\
\hline $\mathrm{k}$ & 7 & 0 & 8 & 0 \\
\hline \multicolumn{4}{|c|}{ Kritik Değerler } & \\
\hline & \multicolumn{3}{|c|}{$\lambda_{2}$} & \\
\hline$\lambda_{1}$ & .4 & .6 & .8 & \\
\hline .2 & $-6.16,-5.59,-5.28$ & $-6.40,-5.74,-5.32$ & $-6.33,-5.71,-5.33$ & \\
\hline .4 & - & $-6.46,-5.67,-5.31$ & $-6.42,-5.65,-5.32$ & \\
\hline .6 & - & - & $-6.32,-5.73,-5.32$ & \\
\hline
\end{tabular}

( Not: Birim kök testi sabit ve trendde kırılmayı dikkate alan Model C üzerinden yapılmıştır. $\widetilde{\tau}, 4$ nolu denklemde yer alan ve açıklanan ilgili test istatistiğini, $\varphi$ ilgili katsayıyı, k gecikme uzunluğunu, $T_{B j}$ ise kırılma tarihlerini vermektedir. Kritik değerler Lee ve Strazicich (2003)'den alınmıştır. $\lambda_{1}$ ve $\lambda_{2}$ 1. ve 2 . kırılmanın lokasyonunu göstermektedir. *** \%1 düzeyinde birim kök sıfır hipotezinin reddine işaret etmektedir.)

LM testinin uygulanması sırasında Lee ve Strazicich (2003, 2004)'i takiben gecikmeli genişletilmiş terim sayısı maksimum 8'den $(\mathrm{k}=8)$ başlayarak belirlenmektedir. Daha sonra süreç, en son genişletilmiş terimin anlamlılığını araştırmaktadır. Bunu takiben, \%10 düzeyindeki 1.645 asimptotik normal değer, ilk farkı alınmış son gecikmeli terimin $t$ istatistiği ile karşılaştırılmaktadır. İki kırılmanın her alternatif kombinasyonundaki optimal $k^{\prime} y ı$ belirledikten sonra, içsel iki kırılmalı LM $t$ test istatistiğinin minimum olduğu yerde kırılmalar belirlenmektedir. Bu şekilde, [0.1T, 0.9T] zaman aralığı boyunca iki kırılma noktasının her muhtemel kombinasyonu incelenmektedir. Burada T örneklem boyutunu göstermektedir. Çoğu yazar (bkz. Sen, 2003, Lee ve Chang, 2007; Lean ve Smyth, 2013)

Model C'nin Model A'ya kıyasla daha üstün olduğunu ifade ettikleri için bu çalışmada Model C'nin sonuçları rapor edilmiştir. Ayrıca, şekil 1 ve şekil 2'de görüldüğü gibi serilerin hem düzey, hem de eğimlerinde kırılmaların olduğu görülmektedir.

Tablo 2'de yer aldığı üzere dolar ve euro için forward ve spot kurlar rassal yürüyüş süreci izlemektedir.
LM testinin bulguları da ADF ve PP birim kök testlerinden elde edilen bulguları doğrulamaktadır. Dolayısıyla, Türkiye'de sonuçlar döviz piyasasının "zayıf formda etkin" olduğunu desteklemektedir.

\subsection{MAKi (2012) Eşbütünleşme Testi Sonuçları}

TL/\$ ve TL/Euro'ya ait forward ve spot kurun her ikisinin rassal yürüyüş süreci izlemeleri nedeniyle (fark durağan sürece sahip olmaları nedeniyle) forward ve spot kurlar arasında eşbütünleşme ilişkisi varlığı Lai ve Lai (1991)'nin modeli baz alınarak (11) nolu denklem üzerinde araştırılmaktadır:

$$
S_{t+1}=a_{0}+\beta f_{t}+\varepsilon_{t+1}
$$

burada $S_{t+1}$ bir dönem sonraki spot kuru, $f_{t}$ cari döneme ait forward kuru temsil etmektedir. Piyasa aktörleri rasyonel beklentilere sahip iken, risk primi yoktur. Modelde, gelecek döneme ait spot kur cari dönem forward kuru ile rassal hata teriminin toplamına eşittir. Rasyonel beklentilerle tutarlı olarak öngörü hataları sıfıra eşit olup piyasada kar sağlayıCı fırsatlar bulunmamaktadır. Piyasa etkin iken $\varepsilon_{t+1}$ şeklinde gösterilen hataların bilgi içermemesi ge- 
reklidir (Çiçek, 2014). Forward kur yansızlık hipotezi durağan olmayan forward ve spot kurların doğrusal bileşiminin durağan olmasını (eşbütünleşmenin varlığını) gerektirmektedir. Eşbütünleşme özelliği piyasa etkinliği için gerekli koşullardan sadece biridir. Piyasa etkinliği ayrıca (11) nolu denklemde $a_{0}=0$ ve $\beta=1$ koşulunun sağlanmasını da gerektirmektedir. $\mathrm{Bu}$ durumda eşbütünleşme vektörünün tahminleri $\alpha=(1,-b,-a)=(1,-1,0)$ şeklinde olup denge ilişkisi ise $S_{t+1}-\beta f_{t}-a_{0}=0$ şeklini almaktadır. Bu koşul sağlanmaz ise forward kur, spot kurun yansız bir tahmincisi değildir. Bu nedenle eşbütünleşme parametrelerine ilişkin kısıt konularak formel biçimde sınanması gerekmektedir. Bu doğrultuda çalışmanın bu aşamasında öncelikle eşbütünleşme ilişkisinin varlığı Maki (2012)'ye ait yapısal kırılmalı test ile sınanmaktadır³.

Tablo 3: Maki (2012) Eşbütünleşme Testi Sonuçları

\begin{tabular}{|l|c|l|}
\hline Modeller (TL/\$) & Test İstatistikleri & \multicolumn{1}{|c|}{$T_{B i}$} \\
\hline Düzey değişim modeli (Model 0) & $-9.584^{* * *}$ & $2007: 01,2007: 07,2008: 03,2008: 08,2011: 03$ \\
\hline Rejim değişim model (Model 1) & $-8.973^{* * *}$ & $2006: 09,2008: 08,2009: 02,2009: 12,2011: 07$ \\
\hline Trendli rejim değişim modeli (Model 2) & $-9.555^{* * *}$ & $2007: 02,2008: 06,2008: 11,2011: 04,2013: 04$ \\
\hline Düzey, trend ve rejim değişim modeli (Model 3) & $-9.419^{* * *}$ & $2007: 07,2008: 08,2009: 02,2009: 08,2011: 04$ \\
\hline Modeller (TL/Euro) & Test İstatistikleri & \multicolumn{1}{|c|}{$T_{B i}$} \\
\hline Düzey değişim modeli (Model 0) & $-9.279^{* * * *}$ & $2008: 08,2009: 02,2010: 05,2011: 04,2013: 04$ \\
\hline Rejim değişim model (Model 1) & -4.709 & $2008: 08,2009: 02,2010: 05,2011: 04,2013: 04$ \\
\hline Trendli rejim değişim modeli (Model 2) & $-9.368^{* * * *}$ & $\begin{array}{l}2008: 09,2010: 02,2010: 10, \\
2011: 11,2012: 06\end{array}$ \\
\hline Düzey, trend ve rejim değişim modeli (Model 3) & $-8.864^{* * *}$ & $2008: 01,2008: 07,2009: 05,2009: 10,2011: 08$ \\
\hline
\end{tabular}

( Not: Maksimum kırılma sayısı Maki (2012)'de olduğu üzere 5, trimaj parametresi 0.05 olarak belirlenmiştir. RV=1 ve $m=5$ için $\% 1$, $\% 5$ ve \%10 için kritik değerler sırasıyla; Model 0 için $-5.958,-5.426$ ve -5.131 'dir. Model 1 için ise, $-6.193,-5.699$ ve -5.449 'dur. Model 2 için, $-6.915,-6.357$ ve -6.057 'dir. Model 3 için de sırasıyla, $-8.004,-7.414$ ve -7.110 şeklindedir. *** \%1 düzeyinde eşbütünleşme yoktur şeklindeki sıfır hipotezinin reddedildiğine işaret etmektedir )

Tablo 3'de görüldüğü üzere forward TL/\$ ve spot $\mathrm{TL} / \$$ arasında her dört modele göre $\% 1$ düzeyinde eşbütünleşme yoktur şeklindeki sıfır hipotezi reddedilmektedir. Aynı şekilde forward TL/euro ve spot TL/ euro arasında da Model 1 hariç diğer üç modele göre eşbütünleşme ilişkisi ya da uzun dönem denge ilişkisi mevcuttur. Bu durumda, döviz piyasasının yarı güçlü formda etkin olmadığı söylenebilmektedir. Eşbütünleşme ilişkisinin varlığı, piyasanın etkinliğini ihlal etmektedir. Çalışmada bir sonraki aşamada eşbütünleşme vektöründeki parametrelere ( $a_{0}=0$ ve $\beta=1$ ) kısıt konulmakta ve forward kur yansızlık hipotezi sınanmaktadır.

\subsection{FMOLS Tahmin Sonuçları}

Tablo 4: FMOLS Tahmin Sonuçları

\begin{tabular}{|c|c|c|}
\hline Değişkenler & $\begin{array}{c}\text { Katsayılar } \\
(\mathrm{TL} / \$)\end{array}$ & $\begin{array}{l}\text { Katsayılar } \\
\text { (TL/Euro) }\end{array}$ \\
\hline$a_{0}$ & $\begin{array}{l}0.112^{* * * *} \\
(4.192)\end{array}$ & $\begin{array}{c}0.070^{*} \\
(1.675)\end{array}$ \\
\hline$\beta$ & $\begin{array}{c}0.643^{* * * *} \\
(10.469)\end{array}$ & $\begin{array}{c}0.861^{* * *} \\
(12.941)\end{array}$ \\
\hline d1 & $\begin{array}{l}0.040^{* *} \\
(2.413)\end{array}$ & $\begin{array}{c}0.027^{*} \\
(1.981)\end{array}$ \\
\hline$d 2$ & $\begin{array}{l}0.049^{* * * *} \\
(2.984)\end{array}$ & $\begin{array}{c}-0.019 \\
(-1.228)\end{array}$ \\
\hline d3 & $\begin{array}{l}0.057^{* * * *} \\
(3.923)\end{array}$ & $\begin{array}{l}0.046^{* *} \\
(2.528)\end{array}$ \\
\hline d4 & $\begin{array}{l}0.055^{* * * *} \\
(4.463)\end{array}$ & $\begin{array}{c}-0.025 \\
(-1.588)\end{array}$ \\
\hline d5 & $\begin{array}{l}-0.054^{* * *} \\
(-3.381)\end{array}$ & $\begin{array}{l}0.034^{* *} \\
(2.301)\end{array}$ \\
\hline
\end{tabular}

( Not: FMOLS tahmini Maki (2012)'deki Model 0 üzerinden yapılmıştır. ${ }^{* * *},{ }^{* * *},{ }^{*}$ sırasıyla $\% 1, \% 5$ ve $\% 10$ düzeyinde anlamlılığı ifade etmektedir. d1, d2, d3, d4 ve d5 ise Model 0 için oluşturulan beş kırılma noktasına ait gölge değişkenleri temsil etmektedirler. 
Tablo 4'de görüldüğü üzere TL/\$ için hem sabit parametre $\left(a_{0}\right)$ hem de forward kura ait katsayı $(\beta)$ $\% 1$ düzeyinde anlamlıdır. 5 kırılmayı temsilen oluşturulan gölge değişkenler de anlamlı görülmektedir. TL/ Euro için ise forward kura ait parametre \%1 düzeyinde anlamlı iken sabit parametre ise sadece $\% 10$ düzeyinde anlamlı çıkmaktadır. Gölge değişkenlerden ise d1, d3 ve d5 çeşitli düzeylerde anlamlı görülmektedir. Ayrıca TL/\$ için forward kur yansızlık hipotezinin sınanması için oluşturulan $a_{0}=0$ ve $\beta=1$ bileşik hipotezi, $1552.811 \chi^{2}(2)$ değeri ile \%1 anlamlılık düzeyinde reddedilmektedir. Aynı şekilde TL/Euro için ise $a_{0}=0$ ve $\beta=1$ bileşik hipotezi 9374.320 $\chi^{2}$ (2) değeri ile \%1 düzeyinde reddedilmektedir. Bu nedenle hem TL/\$, hem de TL/euro için forward kurun spot kurdaki değişimleri açıkladığı fakat forward kurun spot kurun sapmalı bir tahmincisi olduğu söylenebilir. Kısacası bulgular, forward kur yansızık hipotezini (FRUH) destekleyici yönde değildir. Forward kurun yansızlık hipotezinin geçerli olmadığı bulgusu Lai ve Lai (1991) tarafından da elde edilmiştir.

\section{SONUÇ}

Literatürde piyasalarda etkinlik kavramı Fama'dan önce tartışılmaya başlanmakla beraber etkin piyasa kavramını ilk tanımlayan ve etkin piyasa kuramını ortaya koyan Fama olmuştur. Fama (1965, 1970, 1991, 1998) çalışmalarında finansal varlıklar üzerine yansıyan bilgi kümesini piyasa etkinliğinin derecesine göre gruplandırmıştır. Buna göre piyasa fiyatları, zayıf form etkin piyasalarda geçmiş fiyat ve getiri bilgilerini yansıtırken, yarı güçlü form etkin piyasalar hem geçmiş fiyat ve getiri bilgilerini hem de kamuya açıklanan bilgileri yansıtmaktadır. Güçlü form etkin piyasalarda ise piyasa fiyatları, geçmiş fiyat ve getiri bilgilerininin yanı sıra kamuya açıklanan bilgileri ve belli bir grubun tekelindeki bilgileri yansıtırlar.

Bu çalışmanın amacı, Türkiye'de döviz piyasalarının zayıf ve yarı güçlü formlarda etkin olup olmadığı test etmektir. Bu amaç doğrultusunda çalışmada, Türkiye için 2006: 4 - 2013: 12 döneminde TL/\$ ve TL/Euro aylık spot ve forward kurları kullanılmıştır. Veriler, daha önceki çalışmalarda kullanılmamış olan geleneksel birim kök yönteminin zayıf yönlerini gideren yapısal kırılmalı birim kök ve eşbütünleşme yöntemleriyle analiz edilmiştir. Birim kök testi sonuçları Türk döviz piyasasının zayıf formda etkin olduğunu gösterip bir rassal yürüyüş sürecine işaret ederken, eşbütünleşme analizinin sonuçları ise bu piyasaların yarı güçlü formda etkin olmadığına işaret etmiştir. Uzun dönemli eşbütünleşme katsayısını veren tama- men modife edilmiş en küçük kareler tahmincisinin (FMOLS) sonuçları ise forward kur yansızlık hipotezinin (FRUH) Türkiye için geçerli olmadığını ortaya koymuştur.

Zayıf form etkin olan piyasalarda, piyasadaki fiyatların, geçmiş fiyatlardaki tüm mevcut bilgiyi yansıtmaları beklenmektedir. Yarı güçlü form etkin piyasalarda ise piyasadaki fiyatların, bu bilgiye ek olarak diğer döviz kurları ve makroekonomik değişkenlere ilişkin bilgileri de yansıtması beklenmektedir. Türk döviz piyasalarının zayıf formda etkin olup yarı güçlü formda etkin olmadığı sonucuna ulaşıldığından piyasa katılımcıları, geçmiş fiyatlara ilişkin bilgileri kullanarak fazla getiri elde edememelerine karşın, kamuya açıklanan bilgileri kullanarak piyasanın elde ettiği getirinin üzerinde fazladan getiri elde edebilmektedirler. Forward kur yansızlık hipotezinin ihlali ise Türkiye'de forward kurun, spot döviz kurunu yansız biçimde tahmin etmediğini ve bu ilişkiden bir sapma olduğunu göstermektedir.

Çalışmanın mevcut literatüre katkısı, yapısal kırılmalı zaman serisi yöntemlerinin kullanılması ve etkin piyasa analizinin Türk döviz piyasası için yapılarak olası politika sonuçlarının çıkarılmasıdır. Ayrıca, çalışmanın sonuçları, gerek Türk döviz piyasasının etkinliği açısından gerekse döviz piyasaları konusunda araştırma yapanlara, politika yapıcılara ve piyasa katılımcılarına karar verirken bir bakış açısı sağlaması yönünden önem taşımaktadır.

Kamu otoriteleri resmi döviz kurunun düzeyi ile ilgili politikalar belirlerken döviz piyasasının sağladığı bilgiyi kullanıyorlarsa piyasanın etkin olduğu ifade edilebilmektedir. Bir diğer ifadeyle, etkin döviz piyasalarında kamu otoriteleri ya da hükümet önemli bir iktisadi politika değişkeni olan döviz kurundaki hareketleri etkileyememektedir. Kamu otoriteleri ya da hükümetin döviz kurlarına ilişkin kararlar alabildiği, döviz kurlarındaki oynaklığı azaltmak için çeşitli tedbirlerde bulunabildiği veya iktisadi politikalarla döviz kurlarındaki hareketleri belirleyebildikleri durumlarda piyasa etkinliğinden söz etmek mümkün değildir.

Etkin olmayan piyasaların söz konusu olduğu ortamlar ise döviz piyasası katılımcılarının çeşitli alımsatım stratejileri geliştirerek aşırı getiri elde etmelerini mümkün hale getirmektedir. Döviz piyasalarının etkin olmadığı durumlarda kamu otoriteleri, hükümet ve diğer piyasa katılımcıları, döviz kuru hareketlerinin tahminine yönelik modeller geliştirebilmekte ve piyasanın üzerinde getiri elde edebilmektedir. 


\section{SON NOTLAR}

${ }^{1}$ Döviz piyasasının içsel bilgisine giriş yapabilen bir merkez bankası çalışanı bile tutarlı bir temelde döviz piyasasını öngöremez (Wickremasinghe, 2008: 44).

${ }^{3}$ Söz konusu testler yaygın olarak kullanıldığı ve bilindiği için metodolojilerinin tekrarından kaçınılmıştır.

${ }^{4}$ Çalışmada Gregory Hansen (1996a,b) ve Hatemi-j (2008) testleri de uygulanmış ve hem TL/Euro hem de TL/\$ için eşbütünleşmenin olduğu yönünde benzer sonuçlar elde edilmiştir.

\section{KAYNAKLAR}

Abaan, E.D. (1995) “Türkiye'de Serbest Döviz Piyasası Etkinliği” T.C.M.B. Araştırma Genel Müdürlüğü, Tartışma Tebliğ, 9512:253-295.

Ahmad, R., Rhee, S.G. ve Wong, Y.M. (2012) "Foreign Exchange Market Efficiency Under Recent Crises: Asia Pasific Focus" Journal of International Money and Finance, 31:1574-1592.

Akal, M. Birgili, E.V. ve Durmuşkaya, S. (2012) "IMKB30, IMKB100, Dolar ve Avro Futures Piyasalarının Etkinliğinin Testi” Business and Economics Research Journal, 3(4):1-20.

Allen, D.E. ve Taco, P. (2007) "Is the Australian Forex Market Efficient? A Test of the Forward Rate Unbiasedness Hypothesis" www.ecu.edu.au/_data/assets/ pdf_file/0017/40706/ wp0706da.pdf, (15.07.2013).

Azad, A.S.M. (2009) "Random Walk and Efficiency Tests in the Asia Pasific Foreign Exchange Markets: Evidence from the Post - Asian Currency Crisis Data" Research in International Business and Finance, 23: 322-338.

Bachelier, L. (1900) "Theorie de la speculation" Annales Scientifiques de l'Ecole Normale Superieure Ser 3(17):21-86.

Bai, J. ve Perron, P. (1998) "Estimating and Testing Linear Models with Multiple Structural Changes" Econometrica, 66: 47-78.

Baillie, R. T. ve Bollerslev, T. (1994) "Cointegration, Fractional Cointegration, and Exchange Rate Dynamics" The Journal of Finance, 49: 737-745.

Beechey, M., Gruen, D. ve Vickery, J. (2000) "The Efficient Market Hypothesis: A Survey", Reserve Bank of Australia, Research Discussion Paper, 01:1-33.

Bernstein, P.L. (1999) "A New Look at the Efficient Market Hypothesis" The Journal of Portfolio Management, 25(2):1-2.

Campell, J., Lo, A.W. ve Mackinly, A.C. (1997) The Econometrics of Financial Markets, USA New Jersey, Princeton University Press.

Ceylan, A. ve Korkmaz, T. (1993) Uygulamal Portföy Yönetimi, Bursa, Ekin Kitapevi Yayınları.
Cheung, A.W.K., Su, J.J. ve Choo, A.K. (2011) "Are Euro Exchange Rates Markets Efficient? New Evidence from a Large Panel” Griffith Discussion Papers, No: 2011-09.

Coleman, M. (1990) "Cointegration-Based Tests of Daily Foreign Exchange Market Efficiency" Economics Letters, 32 53-59.

Copeland, L.S. (1991) "Cointegration Tests with Daily Exchange Rate Data" Oxford Bulletin of Economics and Statistics, 53:185-198.

Cowles, A. (1933) "Can Stock Market Forecasters Forecast?” Econometrica, 1(3):309-324.

Cuthbertson, K. (1996) Quantitative Financial Economics - Stocks, Bonds and Foreign Exchange - Series in Financial Economics and Quantitative Analysis, England, John Wiley \& Sons.

Çiçek, M. (2014) "A Cointegration Test for Turkish Foreign Exchange Market Efficiency" Asian Economic and Financial Review, 4(4):451-471.

Dickey, D.A. ve Fuller, W.A. (1979) "Distribution of the Estimators for Autoregressive Time Series with a Unit Root" Journal of the American Statistical Association, 74:427-431.

Dowla, A. (1995) "Efficiency of the Black Market for Foreign Exchange" International Economic Journal, 9(2): 89-99.

Engle, R.R. ve Granger, C.W.J. (1987) “Cointegration and Error Correction: Representation, Estimation and Testing" Econometrica, 55:251-276.

Fama, F.E. (1965) "Random Walks in Stock Market Prices", Edwim et al. (eds.) Security Evaluation and Portfolio Analyst, USA, Prentice-Hall Inc.

Fama, F.E., Fisher, L., Jensen, M.C. ve Roll, R. (1969) "The Adjustment of Stock Prices to New Information" International Economic Review, 10(1):1-21.

Fama, F.E. (1970) "Efficent Capital Markets: A Review of Theory Empirical Work" The Journal of Finance, 25(2):383-417.

Fama F.E. (1991) "Efficient Capital Markets: II" The Journal of Finance, 46 (5):1575-1617. 
Fama, F.E. (1998) "Market Efficiency, Long-term Returns and Behavioral Finance" Journal of Financial Economics, 49 (3):283-306.

Giannellis, N. ve Papadopoulos, A. P. (2006) “Testing for Efficiency in Selected Developing Foreign Exchange Markets: An Equilibrium-based Approach" Economic Modelling, 26(1): 155-66.

Gregory, A.W. ve Hansen, B.E. (1996a) "ResidualBased Tests for Cointegration in Models with Regime Shifts" Journal of Econometrics, 70: 99-126.

Gregory, A.W. ve Hansen, B.E. (1996b) "Tests for Cointegration in Models with Regime and

Trend Shifts" Oxford Bulletin of Economics and Statistics, 58:555-560.

Gregory, A.W., Nason, J.M. ve Watt, D.G. (1996) "Testing for Structural Breaks in Cointegration Relationships" Journal of Econometrics, 71:321-341.

Grossman, S.J. ve Stiglitz, J.E. (1980) "On the Impossibility of Informationally Efficient Markets" The American Economic Review, 70(3):393-408.

Hakkio, C.S. ve Rush, M. (1989) "Market Efficiency and Cointegration: An Application to the Sterling and Deutschmark Exchange Markets" Journal of International Money and Finance, 8:75-88.

Hatemi-J, A. (2008) "Tests for Cointegration with Two Unknown Regime Shifts with an Application to Financial Market Integration" Empirical Economics, 35:497-505.

Iwatsubo, K. ve Kitamura, Y. (2008) "Intraday Evidence of the Informational Efficiency of the Yen/ Dollar Exchange Rate" Kobe University Discussion Paper, No:0801.

İbrahim, J., Long, Y., Ghani, H.A. ve Salleh, S.I.M.(2011) "Weak-Form Efficiency of Foreign Exchange Market in the Organisation for Economic Cooperation and Development Countries: Unit Root Test" International Journal of Business and Management, 6(6):55-65.

Jensen, M.C. (1978) "Some Anomalous Evidence Regarding Market Efficiency" Journal of Financial Economics, 6(2-3):95-101.

Johansen, S. (1988) "Statistical Analysis of Cointegration Vectors" Journal of Economic Dynamics and Control, 12: 231-254.

Johansen, S. (1991) "Estimation and Hypothesis Testing of Cointegration Vectors in Gaussian Vector Autoregressive Models” Econometrica, 59: 1551-1580.

Kapetanios, G. (2005) "Unit-Root Testing Against the Alternative Hypothesis of up to m Structural Breaks" Journal of Time Series Analysis, 26:123-133.
Kıyılar, M. (1997) Etkin Pazar Kuramı ve Etkin Pazar Kuramının İrdelenmesi - Test Edilmesi, 1.Baskı, Ankara, S.P.K. Yayını No: 86.

Kisaka, S.E., Rose, N.W., Ganesh, P. ve Gituro, W. (2008) "An Analysis of the Efficiency of the Foreign Exchange Market in Kenya" Economics Bulletin, 14(2):1-13.

Kühl, M. (2007) "Cointegration in the Foreign Exchange Market and Market Efficiency Since the Introduction of the Euro: Evidence based on Bivariate Cointegration Analyses" Göttingen Discussion Papers, 68:1-28.

Lai, K.S. ve Lai, M. (1991) “ A Cointegration Test for Market Efficiency" The Journal of Future Markets, 11(5):567-575.

Laffont, J.J. ve Maskin, E.S. (1990) "The Efficient Market Hypothesis and Insider Trading on the Stock Market" Journal of Political Economy, 98(1):70-93.

Lean, H.H. ve Smyth, R. (2013) "Are Fluctuations in US Production of Renewable Energy Permanent or Transitory?” Applied Energy, 101:483-488.

Lee, C.C. ve Chang, C.P.L. (2007) "Mean Reversion of Inflation Rates in 19 OECD Countries: Evidence from Panel LM Unit Root Tests with Structural Breaks" Economics Bulletin, 3(23):1-15.

Lee, C.C. ve Chang, C.P. (2008) "Unemployment Hysteresis in OECD Countries: Centurial Time Series Evidence with Structural Breaks" Economic Modelling, 25(2):312-325.

Lee, J. ve Strazicich, M. C. (2003) "Minimum LM Unit Root Test with Two Structural Breaks" Review of Economics and Statistics, 85(4):1082-1089.

Lee, J. ve Strazicich, M.C. (2004) "Minimum LM Unit Root Test with One Structural Break", Working Paper 04-17, http://econ.appstate.edu/RePEc/pdf/ wp0417.pdf (20.04.2012).

Lumsdaine, R.L. ve Papell, D.H. (1997) "Multiple Trend Breaks and The Unit Root Hypothesis" The Review of Economics and Statistics, 79(2):212- 218.

MacDonald, R. ve Taylor, M.P. (1992) "Exchange Rate Economics: A Survey" IMF Staff Papers, 39(1):1-57.

Maki, D. (2012) "Tests for Cointegration Allowing for an Unknown Number of Breaks" Economic Modelling, 29(5): 2011-2015.

MacDonald, R. ve Taylor, M.P. (1989) "Foreign Exchange Market Efficiency and Cointegration - Some Evidence from the Recent Float" Economics Letters, 29:63-68.

Megginson, W.L. (1992) Corporate Finance Theory, Addison - Wesley Edicational Publisher Inc., USA. 
Mehrara, M. ve Oryare, A.R. (2012) "Efficient Market Hypothesis in Foreign Exchange Market Before and After the Global Financial Crisis of 2007-08" International Journal of Business and Social Science, 3(9):165-167.

Ortiz, E., Cabello, A., Jesus, R. de ve Johnson R. (2005) "Exchange rates, Market Efficiency and Purchasing Power Parity: Long-Run Tests for the Latin American Currencies" Problemas Del Desarrollo Rensta LatinoAmericana De Economia, 36(141):86-108.

Phillips, P.C.B. ve Perron, P. (1988) “Testing for a Unit Root in Time Series Regression” Biometrika, 75:335-346.

Phillips, P. ve Hansen, B. (1990) "Statistical Inference in Instrumental Variables Regression with I(1) Processes" Review of Economic Studies, 57:99-125.

Perron, P. (1989) "The Great Crash, the Oil Price Shock, and the Unit Root Hypothesis" Econometrica, 57:1361-1401.

Rapp, T. A. ve Sharma, S.C. (1999) "Exchange Rate Market Efficiency: Across and Within Countries" Journal of Economics and Business, 51:423-439.

Samuelson, P.A. (1965) "Proof that Properly Anticipated Prices Fluctuate Randomly" Industrial Management Review, 6(2):41-49.

Sephton, P.S. ve Larsen, H.K. (1991) "Tests of Exchange Market Efficiency: Fragile Evidence from Cointegration Tests" Journal of International Money and Finance, 10:561-570.
Sen, A. (2003) "On Unit-Root Tests when the Alternative is a Trend-Break Stationary Process" Journal of Business and Economics Statistics, 21(1):174-184.

Sewell, M. (2011) "History of the Efficient Market Hypothesis" UCL Research Note, 1-14.

Stiglitz, J.E. (1981) "The Allocation Role of the Stock Market: Pareto Optimality and Competition" The Journal of Finance, 36(2):235-251.

TCMB, http://www.tcmb.gov.tr/

Wickremasinghe, G.B. (2004) "Efficiency of Foreign Exchange Markets: A Developing Country Perspective" ABERU Discussion Paper.

Wickremasinghe, G.B. (2008) "Predictability of Exchange Rates in Sri Lanka: A Test of the Efficient Market Hypothesis" Asian Academy of Management Journal of Accounting and Finance, 3(2):43-59.

Wong, Y.M. ve Ahmad, R. (2013) "Foreign Exchange Markets Efficiency Under Recent Crises: Evidence from the European Markets", www.efmaefm.org/OEFMAMEETINGS / EFMAANNUALMEETING/2013-Reading/papers/ complate-Wong\&Ahmad.pdf, (15.07.2013).

Zivot, E. ve Andrews, D.W.K. (1992) "Further Evidence on the Great Crash, the Oil Price Shock and the Unit Root Hypothesis" Journal of Business and Economic Statistics, 10(3): 251-70. 